\title{
Changes in maize silage fermentation products during aerobic deterioration and effects on dry matter intake by goats
}

\author{
Katrin Gerlach ${ }^{1 *}$, Fabian Roß², Kirsten Weiß ${ }^{3}$, Wolfgang Büscher ${ }^{2}$ and Karl-Heinz Südekum ${ }^{1}$ \\ ${ }^{1}$ Institute of Animal Science, University of Bonn, Endenicher Allee 15, 53115 Bonn, Germany \\ ${ }^{2}$ Institute for Agricultural Engineering, University of Bonn, Nußallee 5, 53115 Bonn, Germany \\ ${ }^{3}$ Faculty of Agriculture and Horticulture, Humboldt University, Invalidenstraße 42, 10115 Berlin, Germany \\ *e-mail: kger@itw.uni-bonn.de
}

\begin{abstract}
Chemical and microbiological changes occurring during aerobic exposure of maize silages and their influence on dry matter (DM) intake and preference by goats were evaluated. Eight maize silages differing in DM content, chopping length and compaction pressure were used for the study. After opening, silages were exposed to air for 8 days (d). In 2-d intervals, silage was stored anaerobically for use in preference trials. During the experimental phase, each possible two-way combination of the five silages ( $d 0, d 2, d 4, d 6$ and $d 8)$ and one standard lucerne hay, was offered as free choice to six goats. Generally, a significant decline occurred in DM intake after $4 \mathrm{~d}$ of aerobic exposure. After $8 \mathrm{~d}$, mean decrease in intake was $53 \%$ in comparison to the fresh silages. Preference when expressed as DM intake was negatively correlated to silage temperature (as difference to ambient), ethanol and ethyl lactate.
\end{abstract}

Key words: forage, preference trial, ruminant, volatile organic compound

\section{Introduction}

Maize is used as a major forage source for ruminants due to its high yields, nutritional value and good ensiling properties (Allen et al. 2003). Maize silage (like all silages) deteriorates on exposure to air, as a result of aerobic microbial activity (Jonsson 1989). Well preserved silages without butyric acid and low contents of acetic acid are particularly susceptible to aerobic deterioration (Cai et al. 1999).

Aerobic deterioration is a significant problem affecting profitability and feed quality throughout the world (Tabacco et al. 2011). Caused by the activities of bacteria, yeasts and moulds, there are changes in the chemical composition of the silage (Lindgren et al. 1985) with resulting loss of dry matter (DM) and nutritional components like residual sugars, lactic acid, acetic acid and ethanol that are used as substrates for oxidation. Additionally, there is an increasing risk of proliferation of potentially pathogenic or otherwise undesirable microorganisms. Mycotoxinproducing moulds, Bacillus cereus and Listeria monocytogenes, for example, can pose serious threats to the quality and safety of milk and animal health (Driehuis and Oude Elferink 2000).

It has long been believed that aerobic deterioration depresses DM intake (DMI), caused by an accumulation of degradation products (Lindgren et al. 1988) or changes in volatile compounds. Data on the effects of volatile compounds like alcohols, acids, esters, aldehydes and ketones on DMI or product quality (e.g. carry-over to milk) are insufficient (Kalač 2010). Silages that have been exposed to air for several days led to a decrease in roughage intake of about $10-20 \%$ in comparison to fresh silage (Wichert et al. 1998, Bolsen et al. 2002). However, in most studies no indication was given as to which substances or properties of the silages were responsible for selective feeding or at which point of deterioration the decline in DMI began.

The aim of the present study was to determine the changes taking place during eight days of aerobic exposure of maize silages and to characterize the effect on DMI and preference by goats. 


\section{Materials and methods \\ Silage preparation and experimental design}

Maize (Zea mays, dual-purpose hybrid 'Amadeo', KWS Saat AG, Einbeck, Germany) was planted on May 5, 2009, at a planting rate of 110,000 plants ha ${ }^{-1}$ at the research station Frankenforst of University of Bonn (Königswinter, Germany, $7^{\circ} 12^{\prime} \mathrm{E}$ and $50^{\circ} 42^{\prime} \mathrm{N}$; 2009 average temperature $10.6^{\circ} \mathrm{C}$, annual precipitation $690 \mathrm{~mm}$, average humidity 71.4\%). Before planting, the soil was fertilized with about $25 \mathrm{~m}^{3} \mathrm{ha}^{-1}$ of swine manure, and at planting, $200 \mathrm{~kg}$ $\mathrm{ha}^{-1}$ of diammonium phosphate was applied. At May 29, 2009, 5 I ha-1 of Zintan Gold Pack (active components: terbuthylazine, metolachlor and mesotrione; Syngenta AG, Basel, Switzerland) was applied as herbicide. Maize was harvested as whole-crop (cutting height $20 \mathrm{~cm}$ ) and chopped at two stages of maturity in 2009 (September 9 and 24). The study was arranged in a $2 \times 2 \times 2$ factorial design consisting of DM content ( 33 and $40 \%$ DM), chopping length (10 and $21 \mathrm{~mm}$ ) and packing density (compaction pressure 0.1 and $0.2 \mathrm{MPa}$ ) in the silo (Table 1).

Table 1. Details about the silage treatments used in the trials

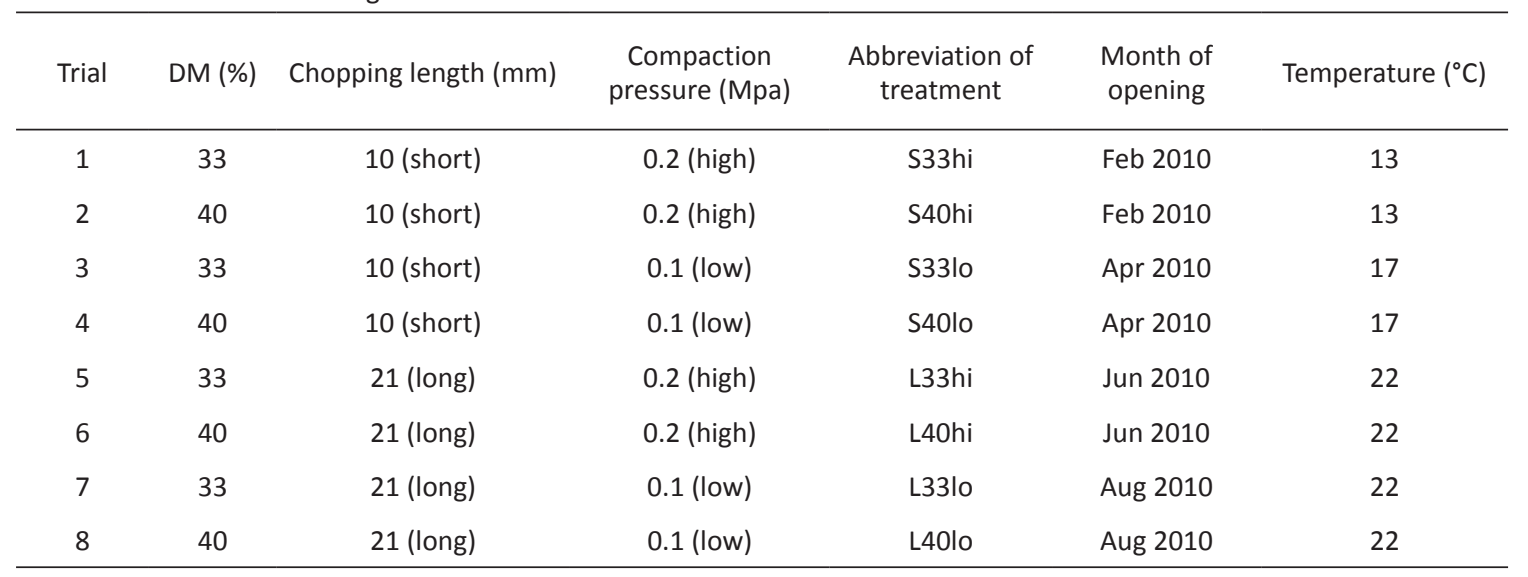

$\mathrm{DM}=$ dry matter, temperature = mean ambient temperature during eight days of aerobic exposure

After harvesting, each crop was immediately ensiled in six 120-I plastic barrels (48 barrels in total; mean density at low and high compaction pressure 235 and $270 \mathrm{~kg} \mathrm{DM} \mathrm{m}^{-3}$, respectively) and stored anaerobically for at least three months. In February 2010, the barrels containing the first two treatments were opened; the silages were taken out, silage from all six barrels was stirred completely for homogenization and stored aerobically on a heap (ground area $3 \mathrm{~m} \times 3 \mathrm{~m}$ ) for eight days. The aerobic exposure trials were conducted indoor with a continuous measurement of ambient temperature (data logger 175-T1, Testo AG, Lenzkirch, Germany). At the day of opening (d0) and at two-day intervals ( $d 2, d 4, d 6$ and $d 8$ after opening), temperature of the silages was measured at three different points (middle, left, right) at a depth of $20 \mathrm{~cm}$ using a digital probe thermometer (TFA Dostmann GmbH \& Co KG, Wertheim, Germany). Aerobic stability was defined as the number of days the silage remained stable before rising more than $3.0 \mathrm{~K}$ above the ambient temperature (Honig 1990). For chemical analyses, a composite sample $(1000 \mathrm{~g})$ of each homogenized silage was taken at the respective sampling days and frozen immediately $\left(-18^{\circ} \mathrm{C}\right)$.

For the preference trials with goats, silage samples from each day of the aerobic exposure ( $d 0, d 2, d 4, d 6$ and d8) were stored anaerobically in polyethylene bags (170 $\mu \mathrm{m}, 400 \mathrm{~mm} \times 600 \mathrm{~mm}$, Innovapac GmbH, Durach, Germany) and sealed with a chamber vacuum-packing machine (MAX-F 46, Helmut Boss Verpackungsmaschinen KG, Bad Homburg, Germany). A single bag filled with about 1.5-2.0 kg silage was offered to each goat per meal. Bags were stored in a dark, dry and cool room $\left(15^{\circ} \mathrm{C}\right)$ until used in the preference trial. Storage time of the silages in the vacuum bags ranged from five to 26 days depending on the day when fed. 


\section{Preference trials}

For each of the eight silage treatments, a preference trial was done at the Institute of Animal Science, University of Bonn, starting in February 2010 (trial 1 and 2), May 2010 (trial 3 and 4), June 2010 (trial 5 and 6) and August 2010 (trial 7 and 8). All trials were conducted with a total of twelve Saanen wethers (German Improved White Goat breed, mean ( \pm SD) body weight $85.8 \mathrm{~kg} \pm 13.9 \mathrm{~kg}$ ), that were divided into two groups (six goats per group) to conduct two trials concurrently. Goats were allocated to groups such that average body weight was the same. Two animals shared an indoor pen of approximately $2 \mathrm{~m} \times 3 \mathrm{~m}$ bedded with straw. They were tied up for the duration time of experimental feeding with the possibility of lying down and accessing water and salt-licks.

Preference trials were carried out according to Buntinx et al. (1997). Each trial started with an adaptation period (Kyriazakis et al. 1990), where single meals of each silage (d0-d8) and lucerne (Medicago sativa L.) hay as standard forage were offered to the animals to associate the silage with postingestive metabolic response, taste and smell produced by the forage. The adaptation period lasted six days and forages were offered in a randomized order. The standard forage was used to compare the different trials. During the experimental phase, each possible 2-way combination of the five aerobic stability treatments and the standard forage $(n=15)$ was presented to each of the six goats. Each forage was offered in a plastic feeding box and the silage pairs were presented side by side. The order of presentation of the pairs and the left-right position of the silages in the pair were randomized in all trials. The weight of the silages was determined before, $30 \mathrm{~min}$ after offering and after feeding to calculate the initial and total DMI after $3 \mathrm{~h}$. During all trials, consumption of total amount of one preferred type was prevented; so there was always a choice between the two forages in the pair. This was guaranteed by offering additional material as soon as the silage fell below $300 \mathrm{~g}$. Each trial lasted 21 days, consisting of six days for adaptation and 15 days for the experiment. Each day, the experimental meal was offered for $3 \mathrm{~h}$, starting at $0730 \mathrm{~h}$. Grass hay was offered for ad libitum consumption at $1530 \mathrm{~h}$ and removed the following morning at $0700 \mathrm{~h}$.

For laboratory analyses, a subsample (1000 g) of each treatment and each stage of aerobic deterioration (d0-d8) was taken out of the polyethylene bag and frozen immediately at the end of each preference trial.

\section{Laboratory analyses}

\section{General analyses}

The silage samples were freeze-dried (Jumo Imago 500, Jumo GmbH \& Co KG, Fulda, Germany) in triplicate replicates. The DM of the silages was then estimated by oven-drying of a duplicate subsample at $105{ }^{\circ} \mathrm{C}$ overnight. A correction of DM $\left(\mathrm{DM}_{\mathrm{cor}}\right)$ for the loss of volatiles during drying was conducted according to Weißbach and Strubelt (2008) using the following equation:

$\mathrm{DM}_{\text {cor }}=\mathrm{DM}+0.95 \times$ sum of fatty acids $(\mathrm{C} 2-\mathrm{C} 6)+0.08 \times$ lactic acid $+0.77 \times 1,2$ propanediol $+1.00 \times$ other alcohols (C2-C6 including butanediol) [ $\left.\mathrm{g} \mathrm{kg}^{-1}\right]$.

Proximate analyses were done according to the German Handbook of Agricultural Research and Analytic Methods (VDLUFA 2012) and method numbers are given. Ash and crude lipids (CL) were analysed using methods 8.1 and 6.1.1., respectively. Crude protein (CP) was determined by Dumas combustion (4.1.2, FP328, Leco 8.1, Leco Instrumente $\mathrm{GmbH}$, Mönchengladbach, Germany).

Neutral detergent fibre (aNDFom, 6.5.1; assayed with heat stable amylase), acid detergent fibre (ADFom; 6.5.2) and acid detergent lignin (ADL, 6.5.3) were analyzed using Ankom 2000 Fiber analyzer (Ankom Technology, Macedon, USA). The aNDFom and ADFom values are expressed exclusive of residual ash.

The Hohenheim gas test (VDLUFA 2012, method 25.1) was conducted for measuring the 24-h in vitro gas production (GP) and estimating the content of metabolizable energy (ME) using the equation of Menke and Steingass (1987):

$\mathrm{ME}\left(\mathrm{MJ} \mathrm{kg}{ }^{-1} \mathrm{DM}\right)=0.136 \times \mathrm{GP}\left(\mathrm{ml} 200 \mathrm{mg}^{-1} \mathrm{DM}\right)+0.0057 \times \mathrm{CP}\left(\mathrm{g} \mathrm{kg}^{-1} \mathrm{DM}\right)+0.000286 \times \mathrm{CL}^{2}\left(\mathrm{~g} \mathrm{~kg}^{-1} \mathrm{DM}\right)+2.20$

Starch was quantified after enzymatic hydrolysis of starch to glucose as described by Brandt et al. (1987). 
Chemical analyses of fermentation products

A subsample (50.0 g) of each silage was used for determination of lactic acid, $\mathrm{pH}$, volatile fatty acids, alcohols (methanol, ethanol, propanol, 1,2 propanediol, 2,3 butanediol), acetone, ammonia and water-soluble carbohydrates (WSC). Furthermore, silages were also analysed for two ethyl esters; ethyl lactate and ethyl acetate.

Cold-water extracts were prepared by blending the frozen samples with a mixture of $300 \mathrm{ml}$ distilled water and 1 $\mathrm{ml}$ toluol, kept overnight in a refrigerator and afterwards filtered using a folded filter paper. Determination of $\mathrm{pH}$ in the extract was done potentiometrically by using a calibrated $\mathrm{pH}$ electrode. Lactic acid was analyzed by HPLC (RI-detector, Shimadzu Deutschland GmbH, Duisburg, Germany) according to Weiß and Kaiser (1995). Volatile fatty acids, alcohols and esters were determined by gas chromatography (flame ionisation detector, Shimadzu) as described by Weiß (2001). Ammonia concentration was analysed colorimetrically based on the Berthelot reaction using a continuous flow analysator (Skalar Analytical B.V., Breda, Netherlands). Concentration of WSC was determined by anthrone method according to von Lengerken and Zimmermann (1991).

\section{Microbiological analyses}

At the day of silage opening (d0) and at the fourth (d4) and eighth day (d8) of aerobic exposure, samples of each silage treatment were taken for determination of microbiological status. A composite sample $(500 \mathrm{~g})$ was taken using sterile gloves and polyethylene bags, then sealed anaerobically, cooled immediately and sent directly to a laboratory (Wessling Laboratorien $\mathrm{GmbH}$, Altenberge, Germany), where all microbiological analyses were conducted the next morning. Aerobic mesophilic bacteria, yeasts and moulds were determined according to VDLUFA (2012, method 28.1.1-28.1.4). All microbial counts were log10-transformed to obtain log-normal distributed data and presented on a wet weight basis. The values below detection level were assigned as value corresponding to half of the detection level to calculate the averages (Tabacco et al. 2009).

\section{Statistical analyses}

All data were analyzed using SAS 9.2 (SAS Institute Inc., Cary, North Carolina, USA). The experimental design allowed statistical analysis by multidimensional scaling (Buntinx et al. 1997) and by traditional analyses. Multidimensional scaling (MDS) is used to develop a spatial arrangement representing the differences expressed as selective forage intake by the animals. For MDS, the difference in preference between a pair of silages was expressed by subtracting the amount of the least preferred forage from the most preferred forage and dividing the difference by the sum of both intakes. In this way, preference was expressed numerically as a relative difference or distance. If an animal consumed equal quantities in one pair, the difference ratio is equal to zero and no preference or distance between the silages was expressed. If only one of the pairs was consumed, the difference ratio is equal to one and the maximum difference in preference between forages is expressed (Buntinx et al. 1997). PROC MDS is an iterative fitting procedure for data with the aim to express distances or relative differences between stimuli (e.g., forages) in an unknown number of orthogonal dimensions, as described by Burns et al (2001). A least squares fit is approximated using an array of points representing the different stimuli. The coordinates of the points are adjusted iteratively until the reduction in residual sum of squares is below a specified level. The residual sum of squares is calculated by comparing the "distance" between the points representing the stimuli and the observed distances or differences between the stimuli. Subsequently, a map is developed with points representing each stimulus. (Burns et al. 2001). Forages with coordinates that are similar in the dimensional space are modelled as similar in preference and, conversely, coordinates being far-of from each other in the dimensional space indicate forages differing in preference (Buntinx et al. 1997). The order of fit is dimension one first, which will generally include the most important variables (most sums of squares), followed by dimension two (Burns et al. 2001).

Each preference trial was also tested by analysis of variance after averaging DMI of each forage (averaged across each combination, $n=6$ ). The analysis of variance only included terms for animal and forage. Within the forage treatments, means were separated using the minimum significant difference (MSD) from the Waller-Duncan kratio t-test (Burns et al. 2001). Simple linear regression was used to examine the relationship between DMI and silage temperature during the days of aerobic exposure (expressed as difference to ambient temperature). Furthermore, correlation coefficients between silage composition and DMI were calculated. Significance was defined at $p<0.05$, whereas a trend towards a significant effect was noted when $0.05 \leq p \leq 0.10$. 


\section{Results \\ Composition of silages}

The chemical composition of whole-crop maize before ensiling is shown in Table 2. Results of chemical composition ranged within expected values.

Table 2. Chemical composition of experimental maize crops before ensiling

\begin{tabular}{|c|c|c|c|c|c|c|c|c|}
\hline \multirow[t]{2}{*}{ Treatment } & \multirow{2}{*}{$\begin{array}{c}\mathrm{DM} \\
\mathrm{g} \mathrm{kg}^{-1}\end{array}$} & Ash & $\mathrm{CP}$ & $\mathrm{CL}$ & aNDFom & ADFom & ADL & \multirow{2}{*}{ 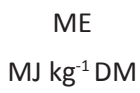 } \\
\hline & & \multicolumn{6}{|c|}{$\mathrm{g} \mathrm{kg}^{-1} \mathrm{DM}$} & \\
\hline S33 & 339 & 35 & 71 & 26 & 409 & 198 & 28 & 10.3 \\
\hline L33 & 341 & 37 & 79 & 30 & 379 & 218 & 21 & 10.5 \\
\hline S40 & 374 & 32 & 72 & 35 & 330 & 182 & 27 & 10.1 \\
\hline L40 & 367 & 39 & 78 & 33 & 329 & 173 & 26 & 10.3 \\
\hline
\end{tabular}

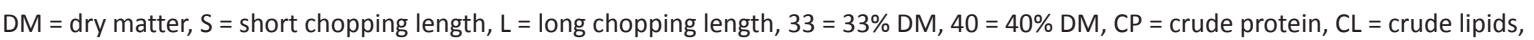
aNDFom = neutral detergent fibre assayed with heat stable amylase and expressed exclusive residual ash, $A D F o m=$ acid detergent fibre expressed exclusive residual ash, $\mathrm{ADL}=$ acid detergent lignin, $\mathrm{ME}=$ metabolizable energy

When the barrels were opened, all silages were free of visible moulds or signs of malfermentation. The chemical composition of the eight silages is given in Table 3.

Table 3. Chemical composition of silages ( $\mathrm{g} \mathrm{kg}^{-1} \mathrm{DM}$ unless otherwise stated) at silo opening, lucerne hay (standard forage) and grass hay (fed for ad libitum intake in the afternoon)

\begin{tabular}{|c|c|c|c|c|c|c|c|c|c|c|}
\hline \multirow[b]{2}{*}{ Variable } & \multicolumn{8}{|c|}{ Silage } & \multirow{2}{*}{$\begin{array}{c}\text { Lucerne } \\
\text { hay }\end{array}$} & \multirow{2}{*}{$\begin{array}{c}\text { Grass } \\
\text { hay }\end{array}$} \\
\hline & S33lo & S33hi & L33lo & L33hi & S40lo & S40hi & L40lo & L40hi & & \\
\hline Dry matter $\left(\mathrm{g} \mathrm{kg}^{-1}\right)$ & 317 & 330 & 315 & 340 & 392 & 379 & 398 & 391 & 908 & 909 \\
\hline Ash & 37 & 36 & 35 & 32 & 37 & 33 & 34 & 36 & 91 & 76 \\
\hline Crude protein & 78 & 76 & 75 & 78 & 72 & 71 & 71 & 77 & 153 & 93 \\
\hline Crude lipids & 31 & 26 & 24 & 33 & 24 & 29 & 35 & 32 & 27 & 16 \\
\hline aNDFom & 384 & 373 & 333 & 357 & 397 & 345 & 302 & 341 & 464 & 592 \\
\hline ADFom & 206 & 214 & 198 & 209 & 231 & 201 & 173 & 194 & 346 & 352 \\
\hline ADL & 25 & 27 & 30 & 26 & 35 & 35 & 24 & 27 & 83 & 52 \\
\hline 24-h gasproduction & 299 & 282 & 290 & 302 & 276 & 288 & 306 & 292 & 225 & 221 \\
\hline \multicolumn{11}{|l|}{$\left(\mathrm{ml} \mathrm{g}{ }^{-1} \mathrm{DM}\right)$} \\
\hline $\mathrm{ME}\left(\mathrm{MJ} \mathrm{kg}{ }^{-1} \mathrm{DM}\right)$ & 11.1 & 10.5 & 10.7 & 11.2 & 10.3 & 10.7 & 11.3 & 10.9 & 9.4 & 8.3 \\
\hline Starch & 351 & 392 & 374 & 383 & 433 & 421 & 362 & 426 & & \\
\hline $\mathrm{pH}$ & 3.9 & 3.9 & 3.9 & 3.9 & 4.0 & 4.0 & 4.0 & 4.0 & & \\
\hline Lactic acid & 59 & 63 & 68 & 56 & 57 & 51 & 54 & 54 & & \\
\hline Acetic acid & 16 & 15 & 17 & 14 & 11 & 11 & 13 & 9 & & \\
\hline Butyric acid & n.d. & n.d. & n.d. & n.d. & n.d. & n.d. & n.d. & n.d. & & \\
\hline Ethanol & 7.4 & 6.4 & 7.6 & 5.5 & 4.7 & 6.0 & 8.1 & 5.9 & & \\
\hline Ethyl acetate $\left(\mathrm{mg} \mathrm{kg}^{-1} \mathrm{DM}\right)$ & 347 & 479 & 173 & 273 & 138 & 400 & 157 & 177 & & \\
\hline Ethyl lactate ( $\left.\mathrm{mg} \mathrm{kg}^{-1} \mathrm{DM}\right)$ & 138 & 157 & 180 & 116 & 176 & 184 & 181 & 161 & & \\
\hline $\mathrm{NH}_{3}-\mathrm{N}\left(\mathrm{g} \mathrm{kg}^{-1}\right.$ of total $\left.\mathrm{N}\right)$ & 72 & 66 & 100 & 80 & 96 & 79 & 97 & 90 & & \\
\hline WSC & 18 & 17 & 20 & 27 & 13 & 9 & 8 & 18 & & \\
\hline Yeasts (log10 cfu g $\left.{ }^{-1}\right)$ & 4.5 & 3.8 & 4.3 & 4.5 & 5.3 & 4.6 & 3.8 & 5.5 & & \\
\hline Moulds (log10 $\left.\mathrm{cfu} \mathrm{g}^{-1}\right)$ & 2.4 & 2.4 & 2.4 & 2.4 & 2.4 & 2.4 & 2.4 & 2.4 & & \\
\hline $\begin{array}{l}\text { Aerobic mesophilic bacteria } \\
\left(\log 10 \mathrm{cfu} \mathrm{g}^{-1}\right)\end{array}$ & 5.5 & 5.0 & 3.7 & 5.6 & 4.5 & 5.0 & 3.4 & 4.7 & & \\
\hline
\end{tabular}

$\mathrm{S}=$ Short chopping length, $\mathrm{L}=$ Long chopping length, $33=33 \% \mathrm{DM}, 40=40 \% \mathrm{DM}$, lo = low packing density, hi = high packing density, $\mathrm{n} . \mathrm{d}$. = below detection limit ( $0.03 \%$ fresh matter), aNDFom = neutral detergent fibre assayed with heat stable amylase and expressed exclusive residual ash;

ADFom = acid detergent fibre expressed exclusive residual ash, ADL = acid detergent lignin, $\mathrm{ME}=$ metabolizable energy, Butyric acid = iso-butyric acid $+n$-butyric acid, iso-valeric acid + n-valeric acid + n-caproic acid, WSC = water-soluble carbohydrates, cfu = colony-forming units 
All silages were well fermented with lactic acid concentrations ranging between 51 and $68 \mathrm{~g} \mathrm{~kg}^{-1} \mathrm{DM}$, moderate levels of acetic acid and no butyric acid. Regarding proximate constituents and fibre fractions, all values were within expected ranges. Ethyl acetate and ethyl lactate could be detected in all silages at concentrations ranging from 138 to $479 \mathrm{mg} \mathrm{kg}^{-1} \mathrm{DM}$ and 116 to $184 \mathrm{mg} \mathrm{kg}^{-1} \mathrm{DM}$, respectively.

Silage samples from each day of aerobic exposure $(\mathrm{d} 0-\mathrm{d} 8)$ were analyzed and chemical composition is shown in Table 4. Regarding the concentration of fermentation variables, strong changes occurred during the aerobic exposure. Degradation of lactic acid and acetic acid $(p<0.001)$ led to elevated $\mathrm{pH}$ value (3.9 to 5.8). Mean content of ethanol and WSC decreased during the eight days of aerobic exposure $(p<0.001)$. In contrast, concentration of other compounds increased or emerged from below detection limit (propionic acid, iso-butyric acid, iso-valeric acid).

\section{Microbiological analysis}

At opening, all silages had low concentrations of yeasts, moulds and aerobic mesophilic bacteria (Table 4). Under aerobic conditions, a rapid development of yeasts occurred resulting in high concentrations at $\mathrm{d} 4 \mathrm{and} \mathrm{d} 8$. The stagnation after $\mathrm{d} 4 \mathrm{can}$ be explained by the standard method of analysis that did not allow yeast counts exceeding $2 \times 10^{7} \mathrm{cfu} \mathrm{g}^{-1}$. Growth of moulds started later and was limited to long cut silages. At d8 of aerobic exposure, it has passed over the orientation value of $5 \times 10^{3} \mathrm{cfu} \mathrm{g}^{-1}$. Short cut silages did not contain numbers of moulds that exceeded orientation values. A similar development was noted in the numbers of aerobic mesophilic bacteria, that were also mainly restricted on the long cut silages.

Table 4. Composition of silages during eight days ( $d 0-\mathrm{d} 8)$ of aerobic exposure, $\left(\mathrm{g} \mathrm{kg}^{-1} \mathrm{DM}\right.$ unless otherwise stated; $\left.\mathrm{n}=8\right)$

\begin{tabular}{|c|c|c|c|c|c|c|}
\hline & do & $\mathrm{d} 2$ & $\mathrm{~d} 4$ & d6 & d8 & SE \\
\hline Dry matter ( $\left.\mathrm{g} \mathrm{kg}^{-1}\right)$ & 360 & 366 & 371 & 389 & 395 & 14 \\
\hline Ash & 35 & 37 & 35 & 35 & 35 & 0.7 \\
\hline Crude protein & 75 & 73 & 76 & 75 & 76 & 1.8 \\
\hline aNDFom & 354 & 370 & 358 & 356 & 362 & 11.9 \\
\hline ADFom & 203 & 209 & 217 & 208 & 206 & 10.3 \\
\hline WSC & $17^{a}$ & $18^{a}$ & $15^{\mathrm{a}}$ & $9^{b}$ & $11^{\mathrm{b}}$ & 1.6 \\
\hline Starch & 387 & 399 & 408 & 438 & 434 & 16.6 \\
\hline 24-h gasproduction ( $\left.\mathrm{ml} \mathrm{g}^{-1} \mathrm{DM}\right)$ & 292 & 293 & 292 & 288 & 285 & 3.0 \\
\hline $\mathrm{ME}\left(\mathrm{MJ} \mathrm{kg} \mathrm{kg}^{-1} \mathrm{DM}\right)$ & 10.8 & 10.8 & 10.9 & 10.7 & 10.6 & 0.1 \\
\hline Lactic acid & $58^{a}$ & $61^{\mathrm{a}}$ & $49^{a}$ & $15^{\mathrm{b}}$ & $8^{b}$ & 3.3 \\
\hline Acetic acid & $13^{a}$ & $12^{\mathrm{a}}$ & $9^{b}$ & $6^{\mathrm{b}}$ & $3^{b}$ & 1.1 \\
\hline iso-butyric acid & n.d. & n.d. & n.d. & 0.4 & 0.4 & 0.1 \\
\hline n-butyric acid & n.d. & n.d. & n.d. & n.d. & n.d. & 0 \\
\hline iso-valeric acid & n.d. & n.d. & n.d. & 0.6 & n.d. & 0.1 \\
\hline n-valeric acid & n.d. & n.d. & n.d. & n.d. & n.d. & 0 \\
\hline n-caproic acid & n.d. & n.d. & n.d. & n.d. & n.d. & 0 \\
\hline Propionic acid & n.d. & n.d. & n.d. & 0.1 & 0.5 & 0 \\
\hline Ethanol & $6.2^{\mathrm{a}}$ & $5.5^{\mathrm{a}}$ & $4.3^{b}$ & $0.6^{c}$ & $0.1^{c}$ & 0.4 \\
\hline Methanol & n.d. & n.d. & n.d. & n.d. & n.d. & 0 \\
\hline Acetone & n.d. & n.d. & n.d. & n.d. & n.d. & 0 \\
\hline $\mathrm{NH}_{3}-\mathrm{N}\left(\mathrm{g} \mathrm{kg}^{-1}\right.$ of total $\left.\mathrm{N}\right)$ & 83 & 99 & 73 & 62 & 55 & 7.8 \\
\hline Ethyl acetate (mg kg-1 DM) & $284^{a}$ & $221^{\mathrm{a}}$ & $114^{\mathrm{b}}$ & $7^{c}$ & n.d. ${ }^{c}$ & 46 \\
\hline Ethyl lactate (mg kg-1 DM) & $159^{\mathrm{a}}$ & $126^{a}$ & $73^{b}$ & $10^{c}$ & n.d. ${ }^{c}$ & 10 \\
\hline $\mathrm{pH}$ & $3.9^{c}$ & $4.0^{c}$ & $4.2^{\mathrm{b}}$ & $5.4^{\mathrm{a}}$ & $5.8^{\mathrm{a}}$ & 0.2 \\
\hline Yeasts (log10 cfu g-1) & $4.6^{\mathrm{b}}$ & n.a. & $7.2^{\mathrm{a}}$ & n.a. & $7.3^{\mathrm{a}}$ & 0.9 \\
\hline Moulds (log10 cfu g $\left.{ }^{-1}\right)$ & $2.4^{\mathrm{b}}$ & n.a. & $2.8^{\mathrm{b}}$ & n.a. & $4.2^{\mathrm{a}}$ & 0.5 \\
\hline Aerobic mesophilic bacteria $\left(\log 10\right.$ cfu g $\left.^{-1}\right)$ & $4.7^{c}$ & n.a. & $5.7^{\mathrm{b}}$ & n.a. & $6.7^{\mathrm{a}}$ & 0.7 \\
\hline
\end{tabular}

a,bMean values within rows having different superscripts differ $(p<0.05)$, n.d. = below detection limit $(0.03 \%$ fresh matter), aNDFom $=$ neutral detergent fibre assayed with heat stable amylase and expressed exclusive residual ash, ADFom = acid detergent fibre expressed exclusive residual ash, $\mathrm{WSC}=$ water-soluble carbohydrates, $\mathrm{ME}=$ metabolizable energy, n.a. = not analyzed. 
Some differences were observed when comparing fresh silages and samples that had been stored in vacuum bags for use in preference trials. Vacuum-sealed silages contained more ethanol, ethyl lactate and ethyl acetate $(p<0.01)$, possibly due to anaerobic yeast activity (data not shown). For calculation of correlation coefficients between silage characteristics and DMI in preference trials, data of vacuum-stored samples were used.

\section{Temperature}

Differences in silage temperature during aerobic exposure are shown in Table 5. Because a constant ambient temperature could not be provided exactly during all trials (see Table 1), silage temperature is expressed as difference to ambient temperature $(\Delta \mathrm{T})$. In most silages, a strong increase of $\Delta \mathrm{T}$ was measured between $\mathrm{d} 4 \mathrm{and} \mathrm{d} 6$ after opening, three of them heated between $\mathrm{d} 2$ and $\mathrm{d} 4 \mathrm{in}$ accordance to their high number of yeasts (long cut silages). Only one silage treatment ( $333 \mathrm{lo}$ ) kept a constant temperature for more than four days. All other silages were already aerobically instable at the fourth day of aerobic exposure, which means they showed an increase in temperature of more than $3.0 \mathrm{~K}$ above ambient temperature.

Table 5. Silage temperature (expressed as difference to ambient temperature $T \Delta$, in $\mathrm{K}$ ) during eight days ( $d 0-d 8)$ of aerobic exposure

\begin{tabular}{llllll}
\hline Silage treatment & $\mathrm{d} 0$ & $\mathrm{~d} 2$ & $\mathrm{~d} 4$ & $\mathrm{~d} 6$ & $\mathrm{~d} 8$ \\
\hline S33lo & -1.5 & -1.8 & 1.0 & 20.5 & 22.4 \\
S33hi & 0.3 & 1.3 & 4.3 & 22.7 & 22.7 \\
L33hi & -2.0 & 0.6 & 13.7 & 12.4 & 28.2 \\
L33lo & 0.9 & 1.3 & 16.0 & 26.5 & 35.0 \\
S40lo & -1.5 & -1.6 & 4.7 & 21.2 & 33.2 \\
S40hi & 0.1 & 1.2 & 4.3 & 21.8 & 33.1 \\
L40hi & -1.7 & 0.0 & 16.4 & 19.2 & 31.1 \\
L40lo & 0.9 & 0.5 & 6.6 & 15.3 & 23.7 \\
\hline
\end{tabular}

$S=$ Short chopping length, $L=$ Long chopping length, $33=33 \%$ DM, $40=40 \%$ DM, lo = low packing density, hi = high packing density.

\section{Animal preference and dry matter intake}

The results of MDS showed that selection between forages was associated with two dimensions. The coordinates for the different silages from all preference trials are shown in Table 6.

Exemplarily, the results for one trial with 30-min and 3-h DMI are depicted in Figure 1. A forage with two positive coordinates is generally strongly preferred while two negative coordinates give evidence for strong avoidance (Burns et al. 2001). For the given trial, there was a strong preference for d0 (located in upper right sector in Figure 1), while lucerne hay and $d 8$ were avoided (located in lower left-hand sector). The others ( $d 2, d 4$ and d6) had one negative dimension and were generally of intermediate preference. The pattern for $30 \mathrm{~min}$ and $3 \mathrm{~h}$ is very similar, for most treatments values lying close together or at least within one quarter. During all trials, d0 was highly preferred in five and $\mathrm{d} 2$ in seven cases. $\mathrm{d} 8$-silages were highly avoided in four of eight trials and never preferred.

According to the MSD calculated with the Waller-Duncan k-ratio t-test, DMI did not differ between silages from d0, d2 and d4 but decreased at d6 ( $p<0.001)$ in six trials. In all trials, DMI was lowest for d8-silages $(p<0.001)$. In the trial with silage L40hi, DMI decreased after two days of aerobic exposure $(p<0.001)$. In contrast, DMI for S33lo was constant for silages d0-d6; only dropping significantly at d8 $(p<0.001)$. Intake of lucerne hay was at the same level as fresh silages. All goats were of good health throughout the study.

Regression analysis showed that 3-h DMI by goats (y) was negatively related to $\Delta \mathrm{T}$ during aerobic exposure, which is shown graphically in Figure 2. 
Table 6. Dry matter intake and stimulus coordinates for the two-dimensional solution to the preference among goats, $\mathrm{n}=40$

\begin{tabular}{|c|c|c|c|c|c|c|c|c|c|}
\hline $\begin{array}{l}\text { Silage } \\
\text { treatment }\end{array}$ & & do & $\mathrm{d} 2$ & $\mathrm{~d} 4$ & d6 & d8 & $\begin{array}{c}\text { Lucerne } \\
\text { hay }\end{array}$ & $\begin{array}{l}\text { Mean } \\
\text { d0-d8 }\end{array}$ & MSD \\
\hline \multirow[t]{4}{*}{ S33lo } & Meal (3 h), g & $651^{a}$ & $657^{a}$ & $650^{a}$ & $625^{\mathrm{a}}$ & $464^{b}$ & $575^{a, b}$ & 609 & 118 \\
\hline & Meal (30 min), g & $345^{a, b}$ & $338^{a, b}$ & $332^{a, b}$ & $365^{\mathrm{a}}$ & $264^{b}$ & $305^{a, b}$ & 329 & 99 \\
\hline & Dimension 1 & 0.82 & -0.49 & 1.38 & 0.60 & -2.0 & -0.31 & & \\
\hline & Dimension 2 & 1.41 & 0.64 & -0.09 & -1.46 & 0.0 & -0.50 & & \\
\hline \multirow[t]{4}{*}{ S33hi } & Meal (3 h), g & $650^{\mathrm{a}}$ & $610^{\mathrm{a}}$ & $633^{a}$ & $380^{\mathrm{b}}$ & $136^{c}$ & $680^{\mathrm{a}}$ & 481 & 128 \\
\hline & Meal (30 min), g & $400^{\mathrm{a}}$ & $312^{b}$ & $339^{a, b}$ & $182^{\mathrm{c}}$ & $73^{d}$ & $299^{b}$ & 261 & 67 \\
\hline & Dimension 1 & -0.54 & 0.85 & 0.57 & -1.39 & 0.43 & 0.08 & & \\
\hline & Dimension 2 & 0.81 & 0.20 & 1.53 & -0.27 & -2.33 & 0.06 & & \\
\hline \multirow[t]{4}{*}{ L33lo } & Meal (3 h), g & $580^{\mathrm{a}}$ & $597^{a}$ & $641^{a}$ & $373^{b}$ & $223^{c}$ & $602^{\mathrm{a}}$ & 483 & 92 \\
\hline & Meal (30 min), g & $324^{a}$ & $339^{a}$ & $394^{a}$ & $160^{\mathrm{b}}$ & $108^{b}$ & $368^{a}$ & 265 & 77 \\
\hline & Dimension 1 & 1.62 & 0.38 & 0.71 & -1.06 & -1.45 & -0.20 & & \\
\hline & Dimension 2 & -0.28 & -1.45 & 0.97 & 0.85 & -0.95 & 0.86 & & \\
\hline \multirow[t]{4}{*}{ L33hi } & Meal (3 h), g & $609^{b, c}$ & $700^{a, b}$ & $720^{\mathrm{a}}$ & $585^{c}$ & $284^{d}$ & $732^{a}$ & 580 & 104 \\
\hline & Meal (30 min), g & $295^{a, b}$ & $364^{a}$ & $361^{a}$ & $269^{b}$ & $104^{c}$ & $317^{a, b}$ & 279 & 73 \\
\hline & Dimension 1 & 0.31 & 0.70 & 1.49 & 0.66 & -2.3 & -0.87 & & \\
\hline & Dimension 2 & -0.45 & -1.14 & 0.44 & 0.61 & -0.24 & 0.78 & & \\
\hline \multirow[t]{4}{*}{ S40lo } & Meal (3 h), g & $723^{a}$ & $779^{a}$ & $752^{\mathrm{a}}$ & $490^{b}$ & $294^{c}$ & $588^{b}$ & 608 & 121 \\
\hline & Meal (30 min), g & $370^{a, b}$ & $425^{a}$ & $437^{a}$ & $215^{c}$ & $123^{d}$ & $326^{b}$ & 314 & 83 \\
\hline & Dimension 1 & -0.29 & 1.86 & -0.03 & 0.56 & -1.54 & -0.55 & & \\
\hline & Dimension 2 & 1.37 & 0.23 & 0.52 & -1.66 & -0.67 & 0.21 & & \\
\hline \multirow[t]{4}{*}{ S40hi } & Meal (3 h), g & $644^{a}$ & $620^{a}$ & $607^{a}$ & $518^{\mathrm{b}}$ & $334^{c}$ & $684^{a}$ & 545 & 97 \\
\hline & Meal (30 min), g & $358^{a, b}$ & $384^{a}$ & $301^{b, c}$ & $272^{c}$ & $156^{d}$ & $314^{b, c}$ & 294 & 66 \\
\hline & Dimension 1 & 0.66 & 0.54 & 1.37 & -1.75 & -1.00 & 0.19 & & \\
\hline & Dimension 2 & -0.56 & 0.61 & 0.23 & 1.19 & -1.75 & 0.28 & & \\
\hline \multirow[t]{4}{*}{ L40lo } & Meal (3 h), g & $598^{a, b}$ & $569^{a, b}$ & $542^{b}$ & $349^{c}$ & $247^{d}$ & $635^{a}$ & 461 & 82 \\
\hline & Meal (30 min), g & $291^{\mathrm{b}}$ & $295^{b}$ & $318^{b}$ & $215^{c}$ & $119^{d}$ & $392^{\mathrm{a}}$ & 248 & 73 \\
\hline & Dimension 1 & -1.35 & -0.28 & -1.00 & 0.10 & 2.11 & 0.42 & & \\
\hline & Dimension 2 & -0.63 & -1.12 & 0.55 & 1.54 & -0.37 & 0.02 & & \\
\hline \multirow[t]{4}{*}{ L40hi } & Meal (3 h), g & $715^{b}$ & $657^{b}$ & $467^{c}$ & $444^{c}$ & $256^{d}$ & $816^{a}$ & 508 & 101 \\
\hline & Meal (30 min), g & $364^{a}$ & $342^{\mathrm{a}}$ & $245^{b}$ & $186^{b}$ & $114^{c}$ & $344^{a}$ & 250 & 66 \\
\hline & Dimension 1 & 0.80 & 0.77 & -0.54 & 0.61 & -2.17 & 0.52 & & \\
\hline & Dimension 2 & -0.2 & -0.96 & -1.29 & 1.37 & 0.44 & 0.64 & & \\
\hline
\end{tabular}

$\mathrm{a}-\mathrm{d}=$ Means within a row with different superscripts differ, MSD = Minimum significant difference (Waller Duncan k-ratio t-test), d0-d8 = days of aerobic exposure after opening of the silo, $S=$ short chopping length, $L=$ long chopping length, $33=33 \%$ DM, $40=40 \%$ DM, lo = low packing density, hi = high packing density. 

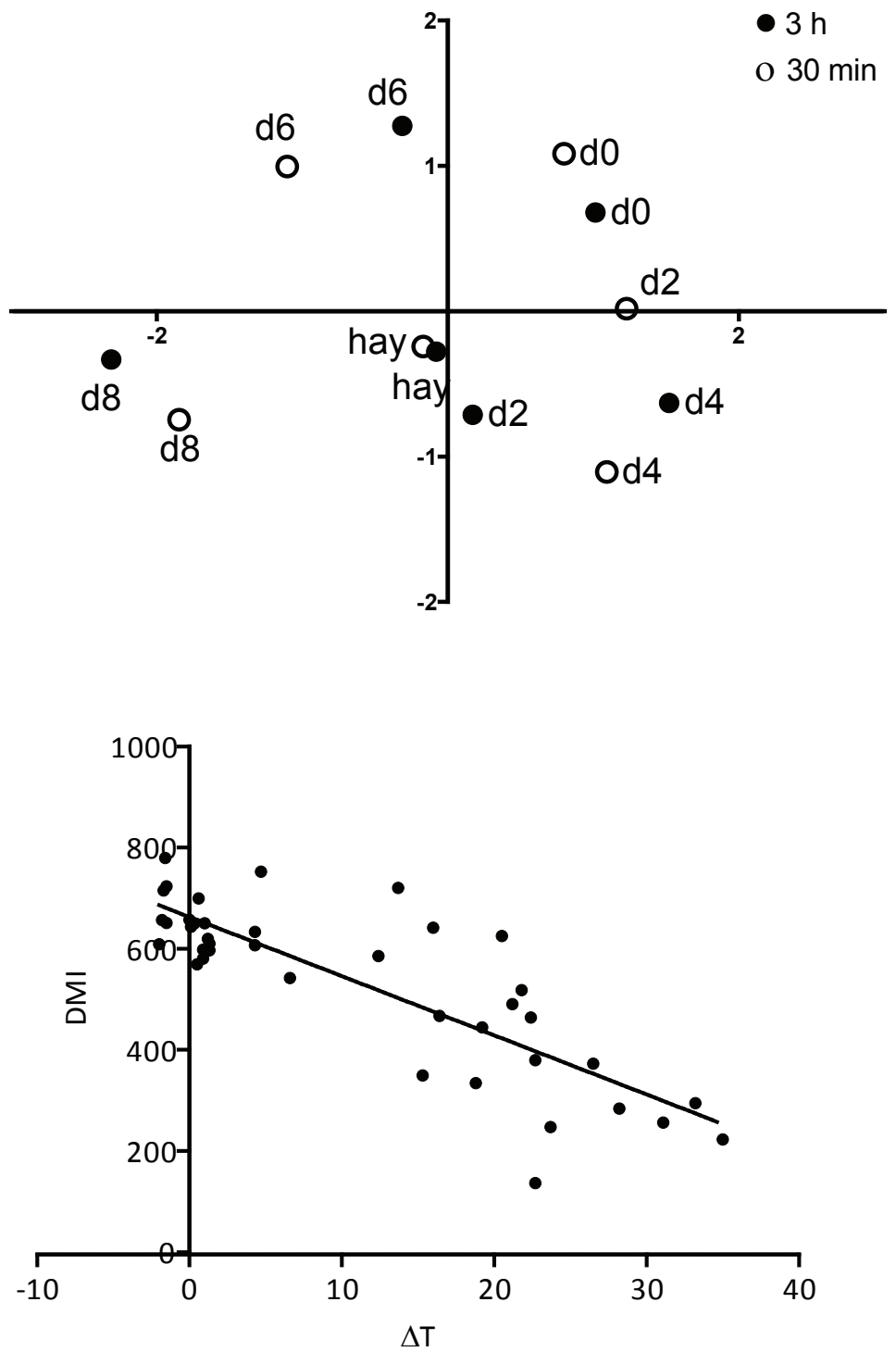

Fig. 1. Multidimensional scaling of the mean preference shown by six goats for five silages (d0-d8) and one lucerne hay (hay) in one preference trial (silage with short chopping length, $33 \%$ dry matter and high compaction pressure) after $30 \mathrm{~min}$ and $3 \mathrm{~h}$ ( $d$ = number of days of aerobic exposure).
Fig. 2. Relationship between dry matter intake (DMI, $\mathrm{g} \mathrm{h} \mathrm{h}^{-1}$ ) of goats and silage temperature during aerobic exposure (expressed as difference to ambient temperature, $\Delta T(K)) ; n$ $=40 ; y=662-11.69 x ; R^{2}=0.681 ; p<0.0001$.

\section{Silage characteristics influencing dry matter intake}

Correlation coefficients were calculated between silage characteristics (of vacuum-stored samples used in preference trials) and DMI of goats (Table 7). A differentiation was made between data referring to silages at all stages of aerobic exposure and the corresponding DMI $(n=40)$ on one hand and only data connected with the fresh silages $(\mathrm{d} 0)$ to disregard the spoilage process $(n=8)$ on the other hand. Across all silages, the strongest and negative correlation was between DMI and $\Delta T$. The DMI had also a weak negative relationship with ethanol, ethyl lactate and $\mathrm{pH}$. In vitro 24-h gas production and ME were positively associated with DMI.

When using only the fresh silages ( $\mathrm{d} 0$ ) that had not undergone aerobic deterioration, DMI was negatively correlated with acetic acid. With an average of $12.9 \mathrm{~g} \mathrm{~kg}^{-1} \mathrm{DM}$, concentrations of acetic acid were generally low. The $\mathrm{pH}$ of these fresh silages showed a trend towards a positive relationship with DMI. Generally, fewer significant correlations were found, most likely due to the lower number of observations. 


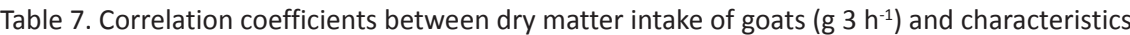
of eight maize silages at day $0-8$ of aerobic exposure and the day of opening (d0) respectively.

\begin{tabular}{lcccc}
\hline Variable & $r(\mathrm{~d} 0-\mathrm{d} 8)$ & $\mathrm{p}$ & $\mathrm{r}(\mathrm{d} 0)$ & $\mathrm{p}$ \\
\hline DM & -0.334 & 0.035 & 0.509 & 0.198 \\
Ash & -0.181 & 0.264 & 0.352 & 0.393 \\
Crude protein & -0.329 & 0.038 & 0.096 & 0.821 \\
Crude lipids & -0.038 & 0.817 & 0.172 & 0.683 \\
aNDFom & 0.150 & 0.362 & -0.175 & 0.679 \\
ADFom & -0.248 & 0.123 & -0.247 & 0.555 \\
ADL & 0.062 & 0.706 & -0.044 & 0.917 \\
ME & 0.415 & 0.008 & -0.063 & 0.882 \\
24-h gas production & 0.513 & 0.001 & -0.114 & 0.789 \\
Starch & -0.020 & 0.902 & 0.143 & 0.736 \\
pH & -0.433 & 0.005 & 0.681 & 0.063 \\
Lactic acid & 0.387 & 0.014 & -0.562 & 0.147 \\
Acetic acid & -0.023 & 0.888 & -0.723 & 0.043 \\
Ethanol & -0.332 & 0.036 & 0.293 & 0.481 \\
Propanol & -0.363 & 0.021 & 0.004 & 0.992 \\
WSC & -0.072 & 0.658 & -0.453 & 0.260 \\
Ethyl acetate & -0.097 & 0.552 & 0.475 & 0.235 \\
Ethyl lactate & -0.327 & 0.039 & 0.427 & 0.291 \\
$\Delta T$ & -0.835 & $<0.0001$ & & \\
\hline Probities & & &
\end{tabular}

Probabilities of $r$ based on $n$ of $40(d 0-d 8)$ and $8(d 0)$

aNDFom $=$ neutral detergent fibre assayed with heat stable amylase and expressed exclusive residual ash, ADFom $=$ acid detergent fibre expressed exclusive residual ash, $A D L=$ acid detergent lignin,

$\mathrm{ME}=$ metabolizable energy, $\mathrm{WSC}=$ water-soluble carbohydrates,

$\Delta \mathrm{T}$ = silage temperature expressed as difference to ambient

\section{Discussion \\ Composition of silages}

This study was conducted to describe the changes occurring during aerobic exposure in maize silages and to evaluate their impact on preference and DMI. Strong shifts were observed in the composition of fermentation products, which is consistent with literature, as reviewed by Pahlow et al. (2003). The concentration of lactic acid decreased significantly in all maize silages during aerobic exposure being nearly depleted after eight days. This can be ascribed to the intense activity of lactate assimilating yeasts, whose population rose above target values within four days of aerobic exposure. A similar decline could be observed in the concentration of acetic acid and WSC. Lactic acid, acetic acid and WSC are the main energy sources for the microorganisms involved in the first phase of aerobic deterioration (McDonald et al. 1991). The microbiological results showed that deterioration was initiated by yeasts followed by moulds and aerobic mesophilic bacteria after the fourth day of aerobic exposure. Moulds have often been observed in advanced stages of aerobic deterioration (Woolford 1990, Pahlow et al. 2003). With reference to suggested target values (VDLUFA 2012), all silages were already spoiled after four days of aerobic exposure. The activity of these organisms leads to the oxidation of fermentation acids and is connected with production of carbon dioxide and water resulting in evolution of heat (McDonald et al. 1991). The $\Delta T$ was strongly correlated with $\mathrm{pH}$, lactic acid, acetic acid and WSC $(r=0.804,-0.882,-0.796,-0.538$, respectively; $p<0.001)$ which is consistent with previous literature (McDonald et al. 1991).

Increase in silage temperature is seen as a convenient indicator for the extent and intensity of aerobic deterioration (Borreani and Tabacco 2010). In our experiment, $\Delta T$ rose drastically after two (long-cut silages) or four days (short-cut silages) of aerobic exposure, due to rapid colonization of lactate assimilating yeasts which have often 
been shown to be capable of rapid growth and are initiators of aerobic deterioration. Maximum silage temperature was measured in silage L33lo with $\Delta \mathrm{T}$ reaching $35.0 \mathrm{~K}$ at d8. It has to be considered that ambient temperature was $22{ }^{\circ} \mathrm{C}$ during this trial which gives good conditions to spoilage organisms like aerobic yeasts mostly being active at $20-30^{\circ} \mathrm{C}$ (Ashbell et al. 2002). Due to different ambient temperatures during aerobic exposure periods, no further conclusions concerning the impact of different treatments (chopping length, DM, compaction pressure) on aerobic deterioration are drawn.

\section{Dry matter intake and preference}

The DMI of different maize silages decreased significantly after four days of aerobic exposure. After eight days it was more than halved, with reductions ranging between $29 \%$ and $79 \%$ in comparison to the fresh silages (d0). In the trial with silage L4Ohi, 3-h DMI decreased after two days of aerobic exposure. Long cut silages with higher contents of DM are especially prone to deterioration after opening, due to restricted fermentation and increased porosity and therefore movement of oxygen into the silage causing more rapid and extensive growth of aerobic microorganisms (Muck et al. 2003). The $\mathrm{pH}$ of L40hi rose from 4.0 to 4.5 within four days, giving evidence of a strong and fast spoilage process. This was also supported by an increase of temperature of $16.4 \mathrm{~K}$ during these four days. In contrast, DMI was constant for six days in the trial with silage S33lo. When looking at the $\Delta T$ in this treatment it can be assumed that the spoilage process started later, therefore temperature remained steady up to the sixth day after opening the silo. This prolonged aerobic stability might be due to the relatively high content of acetic acid in this treatment.

Few other studies dealing with the topic also reported a strong (Wichert et al. 1998) or slight decline (Bolsen et al. 2002) in feed intake after some days of aerobic exposure. Since oxygen can penetrate the silage for 1 to $2 \mathrm{~m}$ when still being in the silo (Weinberg and Ashbell 1994), air contact is not restricted on face and feed-out, thus days with air contact can easily exceed time interval of four days under field conditions. As DMI is one of the most important factors determining productivity in milk or beef production, care should be taken to avoid air contact and consequently aerobic deterioration in maize silages. Unfortunately, DM losses have not been calculated in these studies. With reference to literature (McGechan 1990, Bolsen et al. 1993, Tabacco et al. 2011), losses can account for up to $20 \%$ of the total stored DM and up to $70 \%$ in the peripheral areas and near the sidewalls of the bunkers. When adding these losses to the decline in DMI that occurred in the preference trials reported above, the negative consequences of aerobic deterioration are detrimental. However, data presented here are based on preference experiments. Keady and Murphy (1998) observed that differences in DMI were much stronger when cows were having the possibility to choose between two or more feedstuffs in comparison with single-choice experiments. Nevertheless, results give an impression of the potential in DMI that is lost when feeding spoiled silages in comparison to fresh ones. Low preference for deteriorated silages may probably result in greater feed sorting and lower intakes when animals have a choice of different feedstuffs. It might be interesting for studies to examine the impact of deterioration in single-choice experiments.

\section{Silage characteristics influencing dry matter intake}

The impact of deterioration on DMI and preference was strongly negative, but it was difficult to attribute the decline to a single compound. Some fermentation products (ethyl lactate, ethanol) were negatively related to silage intake, but correlation coefficients were weak.

With restriction to the fresh silages without aerobic deterioration, DMI was strongly negatively correlated to acetic acid, which is in agreement with the findings of Buchanan-Smith (1990) where concentrations of acetic acid were shown to be responsible for a decrease in DMI by sheep in a linear manner. In meta-analyses on the effect of fermentation quality on DMI by dairy cows (Eisner et al. 2006, Eisner 2007), acetic acid was the strongest single predictor of DMI when silages and concentrates were offered separately. Though, the dataset used was mainly based on grass silages or mixtures of grass and maize silages. New findings of Krizsan et al. (2012) showed that an addition of acetic acid to wilted grass silages fed to growing steers reduced silage DMI. However, the reduction equalled the amount provided by the added substances, so no differences in total DMI were observed. From our point of view, a lower DMI caused by slightly increased amounts of acetic acid in fresh silages is compensated by the better aerobic stability and therefore a smaller decline in DMI as a consequence of aerobic deterioration, as seen with silage S33lo. 
Another component negatively related to DMI in this study was ethanol. Huhtanen et al. (2002) and Krizsan and Randby (2007) did not find a negative impact of ethanol on DMI, while results of Hetta et al. (2007) showed a positive effect that eventually could be an associative effect due to the negative correlation between concentrations of ethanol and ammonia- $\mathrm{N}$ in that study.

Correlation of $\mathrm{pH}$ with DMI was ambiguous, with different results for fresh and aerobically stored silages. For the fresh silages (that had not undergone aerobic deterioration), there was a positive relationship between $\mathrm{pH}$ and DMI. This is consistent with literature, which reported similar positive relationship for fresh silages (Erdman 1988, Dulphy and Van Os 1996, Eisner 2007). In well fermented silages with a low pH, DMI increases when silage pH increases. This positive effect implies a decrease in acidity caused by less fermentation without excessive formation of ammonia-N and fermentation acids (Dulphy and Van Os 1996). Otherwise, correlation of the complete silage dataset (fresh as well as spoiled silages) with DMI shows a negative relationship. Here, the effect of silage $\mathrm{pH}$ on intake seems to be a direct consequence of the spoilage processes. Steen et al. (1998) observed a quadratic relationship between $\mathrm{pH}$ and $\mathrm{DMI}$ with a slight positive value at low $\mathrm{pH}$ followed by a negative relationship at high $\mathrm{pH}$. Huhtanen et al. (2002) proposed that this might be caused by the contrary influence of acidity at low $\mathrm{pH}$ and poor fermentation with high concentrations of ammonia $\mathrm{N}$ and volatile fatty acids at high $\mathrm{pH}$.

Ethyl lactate had a weak negative influence on DMI. In other trials, esters were the most abundant class of volatile compounds in red clover silages (Figueiredo et al. 2007) as well as in grass silages (Mo et al. 2001) with ethyl esters being the predominant subclass of all esters (Figueiredo et al. 2007). Since esters are known to be odorant, they could have an effect on the taste of a silage and consequently on feed intake (Mo et al. 2001). Also Kristensen et al. (2010) expected them to contribute to the silage flavour due to their volatility. Many esters have low odour thresholds, so they can already be noticed in the parts per million ranges. To our knowledge, the effect of different ethyl esters in silages on voluntary feed intake by ruminants has not been studied previously. There may be need for further studies, since they have recently been observed in considerable amounts in fresh and well fermented silages (Weiß et al. 2011, Weiß and Auerbach 2012), where ethyl acetate and ethyl lactate showed a strong correlation with ethanol, which was also confirmed in our study $(r=0.868$ and $r=0.918, p<0.001$, data not shown).

By far the strongest correlation was between $\mathrm{DMI}$ and $\Delta \mathrm{T}$. The fact that temperature measured in the silage was a better predictor than any other analyzed constituent emphasizes the difficulty to identify chemical reactions being responsible for decreases in preference caused by aerobic spoilage. Nevertheless, it also underlines the suitability of temperature measurement for daily use, as recommended by Borreani and Tabacco (2010) to improve silage management. The target value of $5{ }^{\circ} \mathrm{C}$ for maximum $\Delta \mathrm{T}$ given by Spiekers et al. (2009) for practical use was proven to be appropriate.

In the present study, goats were used as model animals for cattle. Strong evidence can be found in literature that their feeding and preference behaviour are very similar (Squires 1982, Burns et al. 2001). Nevertheless, continuative studies with dairy cows and beef cattle dealing with the topic presented here are needed to verify that assumption.

In conclusion, this study demonstrated that strong changes concerning the fermentation products of maize silage occurred during eight days of aerobic exposure. Counts of spoilage organisms, especially yeasts rose above target values within four days. There was a strong impact of deterioration on feed intake and preference by goats, marked by a decrease of DMI after four days of exposure shown by goats in choice situations. Temperature measured in the silage was the best predictor for DMI in comparison with any single silage constituent. It can be recommended to limit exposure of silages to oxygen during storage and feed-out as much as possible because of its detrimental effects on DMI.

\section{Acknowledgements}

This study was supported by the "Deutsche Forschungsgemeinschaft" (DFG, German Research Foundation, SU 124/22-1 and BU 1235/5-1). We thank Nadja Wahl and Petra Jacquemien, University of Bonn and the team of Central Analytical Laboratory, Humboldt University Berlin, for support in chemical analyses and Dr. Young Anele for language editing. 


\section{References}

Allen, M.S., Coors, J.G. \& Roth, G.W. 2003. Corn Silage. In: Buxton, D.R., Muck, R.E., Harrison, J.H. (eds.). Silage Science and Technology. Madison: Amer Soc Agronomy, Crop Sci Soc America, Soil Sci Soc America, p. 547-608.

Ashbell, G., Weinberg, Z.G., Hen, Y. \& Filya, I. 2002. The effects of temperature on the aerobic stability of wheat and corn silages. Journal of Industrial Microbiology and Biotechnology 28: 261-263.

Bolsen, K.K., Dickerson, J.T., Brent, B.E., Sonon, R.N., Dalke, B.S., Lin, C., \& Boyer, J.E. 1993. Rate and extent of top spoilage losses in horizontal silos. Journal of Dairy Science 76: 2940-2962.

Bolsen, K.K., Whitlock, L.A. \& Uriarte-Archundia, M.E. 2002. Effect of surface spoilage on the nutritive value of maize silage diets. Proceedings XIII International Silage Conference. Auchinruive, UK, p. 76-77.

Borreani, G. \& Tabacco, E. 2010. The relationship of silage temperature with the microbiological status of the face of corn silage bunkers. Journal of Dairy Science 93: 2620-2629.

Brandt, M., Schuldt, A., Mannerkorpi, P. \& Vearasilp, T. 1987. Zur enzymatischen Stärkebestimmung im Darminhalt und Kot von Kühen mit hitzestabiler Amylase. Archives of Animal Nutrition 37:455 (Abstract, in German).

Buchanan-Smith, J.G. 1990. An investigation into palatability as a factor responsible for reduced intake of silage by sheep. Animal Production 50: 253-260.

Buntinx, S.E., Pond, K.R., Fisher, D.S. \& Burns, J.C. 1997. The utilization of multidimensional scaling to identify forage characteristics associated with preference in sheep. Journal of Animal Science 75: 1641-1650.

Burns, J.C., Fisher, D.S. \& Mayland, H.F. 2001. Preference by sheep and goats among hay of eight tall fescue cultivars. Journal of Animal Science 79: 213-224.

Cai, Y., Benno, Y., Ogawa, M. \& Kumai, S. 1999. Effect of applying lactic acid bacteria isolated from forage crops on fermentation characteristics and aerobic deterioration of silage. Journal of Dairy Science 82: 520-526.

Driehuis, F. \& Oude Elferink, S.J.W.H. 2000. The impact of the quality of silage on animal health and food safety: A review. Veterinary Quarterly 22: 212-216.

Dulphy, J.P. \& Van Os, M. 1996. Control of voluntary intake of precision-chopped silages by ruminants: a review. Reproduction Nutrition Development 36: 113-135.

Eisner, I. 2007. Statistische Analyse der Beziehungen zwischen Fermentationscharakteristika von Silagen und der Futteraufnahme sowie Milchleistung und Milchzusammensetzung bei Kühen. Dissertation Christian-Albrechts-Universität, Kiel, Germany. 154 p. (in German).

Eisner, I., Südekum, K.-H. \& Kirchhof, S. 2006. Beziehungen zwischen Fermentationscharakteristika von Silagen und der Futteraufnahme von Milchkühen Übersichten zur Tierernährung 34: 197-221. (in German).

Erdman, R. 1988. Forage pH effects on intake in early lactation dairy cows. Journal of Dairy Science 71: 1198-1203.

Figueiredo, R., Rodrigues, A.I. \& do Céu Costa, M. 2007. Volatile composition of red clover (Trifolium pratense L.) forages in Portugal: The influence of ripening stage and ensilage. Food Chemistry 104: 1445-1453.

Hetta, M., Cone, J.W., Bernes, G., Gustavsson, A.M. \& Martinsson, K. 2007. Voluntary intake of silages in dairy cows depending on chemical composition and in vitro gas production characteristics. Livestock Science 106: 47-56.

Honig, H. 1990. Evaluation of aerobic stability. Grass and forage reports. Special isssue Proceedings EUROBAC Conference 1986 3: 76-82.

Huhtanen, P., Khalili, H., Nousiainen, J.I., Rinne, M., Jaakkola, S., Heikkila, T. \& Nousiainen, J. 2002. Prediction of the relative intake potential of grass silage by dairy cows. Livestock Production Science 73: 111-130.

Jonsson, A. 1989. The role of yeasts and clostridia in silage deterioration: identification and ecology. Rapport Swedish University of Agricultural Sciences, Uppsala, Sweden. 51 p.

Kalač, P. 2010. The effects of silage feeding on some sensory and health attributes of cow's milk: A review. Food Chemistry 125 : 307-317.

Keady, T.W.J. \& Murphy, J.J. 1998. A note on the preferences for, and rate of intake of, grass silages by dairy cows. Irish Journal of Agricultural and Food Research 37: 87-91.

Kristensen, N.B., Sloth, K.H., Højberg, O., Spliid, N.H., Jensen, C., Thøgersen, R. 2010. Effects of microbial inoculants on corn silage fermentation, microbial contents, aerobic stability, and milk production under field conditions. Journal of Dairy Science 93: 3764-3774.

Krizsan, S.J. \& Randby, Å.T. 2007. The effect of fermentation quality on the voluntary intake of grass silage by growing cattle fed silage as the sole feed. Journal of Animal Science 85: 984-996.

Krizsan, S.J., Randby, Å.T. \& Westad, F. 2012. Effect of acetic acid, caproic acid and tryptamine on voluntary intake of grass silage by growing cattle. Grass and Forage Science 67: 361-368.

Kyriazakis, I., Emmans, G.C. \& Whittemore, C.T. 1990. Diet selection in pigs: choices made by growing pigs given foods of different protein concentrations. Animal Production 51: 189-199.

Lindgren, S., Pettersson, K., Jonsson, A., Lingvall, P. \& Kaspersson, A. 1988. Silage inoculation: selected strains, temperature, wilting and practical application. Swedish Journal of Agricultural Research 15: 9-18.

Lindgren, S., Pettersson, K., Kaspersson, A., Jonsson, A. \& Lingvall, P. 1985. Microbial dynamics during aerobic deterioration of silages. Journal of the Science of Food and Agriculture 36: 765-774. 
McDonald, P., Henderson, A.R. \& Heron, S.J.E. 1991. The Biochemistry of Silage. Chalcombe Publications, Marlow, UK. 340 p. McGechan, M.B. 1990. A review of losses arising during conservation of grass forage: Part 2, storage losses. Journal of Agricultural Engineering Research 45: 1-30.

Menke, K.H. \& Steingass, H. 1987. Schätzung des energetischen Futterwerts aus der in vitro mit Pansensaft bestimmten Gasbildung und der chemischen Analyse. II. Regressionsgleichungen. Übersichten zur Tierernährung 15: 59-94. (in German).

Mo, M., Selmer-Olsen, I., Randby, Å.T., Aakre, S.E. \& Asmyhr, A. 2001. „New“ fermentation products in grass silage and their effects on feed intake and milk taste. Proceedings of the 10th International Symposium on Forage Conservation. Brno, Czech Republic, p. 98-99.

Muck, R.E., Moser, L.E. \& Pitt, E.E. 2003. Postharvest factors affecting ensiling. In: Buxton, D.R., Muck, R.E., Harrison, J.H. (eds.). Silage Science and Technology. Madison, Wisconsin, USA: American Society of Agronomy, Crop Science Society of America, Soil Science Society of America. p. 251-304.

Pahlow, G., Muck, R.E., Driehuis, F., Oude Elferink, S.J.W.H. \& Spoelstra, S.F. 2003. Microbiology of ensiling. In: Buxton, D.R., Muck, R.E., Harrison, J.H. (eds.). Silage Science and Technology. Madison: ASA, CSSA, SSSA, p. 31-93.

Spiekers, H., Potthast, V. \& Nussbaum, H. 2009. Erfolgreiche Milchviehfütterung: DLG-Verlags-GmbH, Frankfurt am Main, Germany. 576 p. (in German).

Squires, J. 1982. Dietary overlap between sheep, cattle, and goats when grazing in common. Journal of Range Management 35 : 116-119.

Steen, R.W.J., Gordon, F.J., Dawson, L.E.R., Park, R.S., Mayne, C.S., Agnew, R.E., Kilpatrick, D.J. \& Porter, M.G. 1998. Factors affecting the intake of grass silage by cattle and prediction of silage intake. Animal Science 66: 115-127.

Tabacco, E., Piano, S., Cavallarin, L., Bernardes, T.F. \& Borreani, G. 2009. Clostridia spore formation during aerobic deterioration of maize and sorghum silages as influenced by Lactobacillus buchneri and Lactobacillus plantarum inoculants. Journal of Applied Microbiology 107: 1632-1641.

Tabacco, E., Righi, F., Quarantelli, A. \& Borreani, G. 2011. Dry matter and nutritional losses during aerobic deterioration of corn and sorghum silages as influenced by different lactic acid bacteria inocula. Journal of Dairy Science 94: 1409-1419.

VDLUFA. 2012. VDLUFA-Methodenbuch, Bd. III. Die Chemische Untersuchung von Futtermitteln. 8. Erg. 2012: VDLUFA-Verlag, Darmstadt, Germany. (in German). 2190 p.

von Lengerken, J. \& Zimmermann, K. 1991. Handbuch Futtermittelprüfung: Deutscher Landwirtschaftsverlag Berlin, Germany. 651 p. (in German).

Weinberg, Z.G. \& Ashbell, G. 1994. Changes in gas composition in corn silages in bunker silos during storage and feedout. Canadian Agricultural Engineering 36: 155-158.

Weiß, K. 2001. Gärungsverlauf und Gärqualität von Silagen aus nitratarmen Grünfutter. Dissertation Humboldt-Universität Berlin, Germany. 181 p. (in German).

Weiß, K. \& Auerbach, H. 2012. Occurence of volatile organic compounds and ethanol in different types of silages. In: Kuoppala, K., Rinne, M. \& Vanhatalo, A. (eds). Proceedings XVI International Silage Conference. Hämeenlinna, Finland: MTT Agrifood Research Finland, University of Helsinki, p. 128-129.

Weiß, K., Gerlach, K. \& Südekum, K.-H. 2011. Flüchtige Substanzen in Maissilagen in Abhängigkeit von Silierbedingungen und aerober Lagerungsdauer. VDLUFA-Schriftenreihe 67: 534-540. (in German).

Weiß, K. \& Kaiser, E. 1995. Milchsäurebestimmung in Silageextrakten mit Hilfe der HPLC. Wirtschaftseigene Futter 41: 69-80. (in German).

Weißbach, F. \& Strubelt, C. 2008. Correcting the dry matter content of maize silages as a substrate for biogas production. Landtechnik 63: 82-83.

Wichert, B., Kienzle, E. \& Bauer, J. 1998. Palatability and intake of silage in dairy cows, in relation to hygienic quality. Journal of Animal Physiology and Animal Nutrition 80: 253-259.

Woolford, M.K. 1990. The detrimental effects of air on silage. Journal of Applied Microbiology 68: 101-116. 